\title{
Does New Regulation Points to an Effective Use of Strategic Environmental Assessment? Lessons from Democratic Republic of Congo
}

\author{
Marcelo Montaño ${ }^{{ }^{*}}$, Ghislain Mwamba Tshibangu ${ }^{1,2}$, Anne Caroline Malvestio ${ }^{1,3}$ \\ ${ }^{1}$ Sao Carlos School of Engineering, University of Sao Paulo, Sao Carlos, Brazil \\ ${ }^{2}$ Impact Assessment Agency of Canada, Quebec, Canada \\ ${ }^{3}$ Federal University of Uberlandia, Uberlandia, Brazil \\ Email: *minduim@sc.usp.br
}

How to cite this paper: Montaño, M. Tshibangu, G.M. and Malvestio, A.C. (2021) Does New Regulation Points to an Effective Use of Strategic Environmental Assessment? Lessons from Democratic Republic of Congo. Journal of Environmental Protection, 12, 1102-1127.

https://doi.org/10.4236/jep.2021.1212065

Received: November 20, 2021

Accepted: December 13, 2021

Published: December 16, 2021

Copyright (c) 2021 by author(s) and Scientific Research Publishing Inc. This work is licensed under the Creative Commons Attribution International License (CC BY 4.0).

http://creativecommons.org/licenses/by/4.0/

\section{(c) (i) Open Access}

\begin{abstract}
To date, an important debate regarding the use of Strategic Environmental Assessment in policy and plan-making seems to focus on whether to reform or develop SEA regulations. Despite the well-established theoretic relevance of legislation, there is only little empiric evidence, moreover in developing countries. This paper aims to verify the contributions of new regulations to a proper use of SEA, based on the case of the Democratic Republic of Congo. Both the SEA practice previously to the legislation reform and the newly introduced SEA system established by the new regulation were characterized. The new regulation was verified against the previous practice of SEA within the country and the compliance with international performance criteria. The outcomes suggest that the overall quality of SEA documentation is still in need of major improvements. Gaps include alternatives development and impacts monitoring. The biggest performance limitations of the new regulation are related to the length of SEA processes, public consultation, SEA information to provide, and alternatives to consider. Finally, it is suggested that regulation reform or straightforward adoption might not be enough to support an effective use of SEA.
\end{abstract}

\section{Keywords}

SEA Systems, Effectiveness, Regulation, Developing Countries, Democratic Republic of Congo 


\section{Introduction}

Strategic Environmental Assessment (SEA) is a supporting tool that adds scientific rigour to PPP decision-making and is one of the most widely used instruments to assist in the incorporation of environmental considerations into Policy, Plan and Programme (PPP) levels [1] [2].

Developing countries have been proving to be much slower in the adoption of this instrument [3] [4], though it must be recognized that some progress has been made in recent years [5] [6]. During the last decade, a number of developing nations/areas have passed formal legislation related to the use of SEA, e.g. Mainland China [7], Vietnam [8], Chinese Taipei [9]. Besides, if SEA is not formally required, voluntary practice might take place [10] [11].

There is currently a strong call to either reform or adopt legal arrangements for SEA in developing countries [12] [13]. However, there is no consensus on whether a formal and mandatory SEA would contribute to an effective use of this tool [14] [15] [16]. In this sense, regulations and guidelines are recognized as means to promote a consistent practice based on explicit requirements [12] [13], which is related to the capability of institutions and society to ensure a proper use of SEA tools [17].

Although SEA has been a recurrent research subject for well over two decades, most of the professional literature reflects the perspective of developed countries [18]. There is, however, a clear interest for empirical research in developing countries in order to support the transposition of SEA principles, concepts and approaches to the different contexts [10]. Therefore, the present paper aims to verify the contributions of new regulations to a proper use of SEA, based on the case of a recent introduction of SEA within formal requirements in the Democratic Republic of Congo. SEA practice was then characterized in terms of core principles advocated in SEA literature, considering two distinct periods: prelegislative reform and after the establishment of a formal SEA system introduced by the legislation.

The questions underlying this study included: 1) how close to international best practice principles was SEA practice in the DRC before its transposition into national legislation? 2) to what extent the introduced legal framework denotes proximity to SEA's best practice principles? and 3) what could be the expected impacts on SEA practice in the country from the implementation of the new SEA system?

The case study provides an opportunity to test the adequacy of new SEA legislation to its specific context of operation and, also, whether the new regulation reflects somehow the cumulated experience of previous practice, in order to foster SEA effectiveness.

The paper is organized in six sections. After this introduction, the conceptual background is provided. In Section 3, the methodology is described, followed by the discussion of the results (Section 4). In the subsequent sections, lessons from the case study are drawn (Section 5) and main conclusions are summarized (Section 6). 


\section{Background}

The adoption of legal requirements for Environmental Assessment (EA) in both developed and developing countries has been described and assessed [18], in some cases based not only on the review of EA practice before and after the adoption of legislative requirements (see, e.g., [19] [20] [21] [22] but also on the necessity of adopting regulations [15] [16] [23].

Developing countries have adopted SEA to a great extent stimulated by Multilateral Development Agencies [8] which have adopted SEA as part of their safeguard policies [4] [24].

As formal SEA systems were originally established in developed countries [25], their introduction in developing countries requires caution [26]. Moreover, high level commitment and capacity-building for conducting SEA are crucial prior to its introduction in a given country, or it may be pointless to adopt mandatory requirements [17] [27].

In this context, one of the main questions raised in the literature is related to the lack of legal requirements for a systematic use of SEA in developing countries [5] [6] [28] and, mainly, the extent to which a formal SEA system can help fostering an effective use of SEA.

It is argued that formal requirements to SEA can be particularly relevant to secure enough room to the influence of SEA within plan-making [10] [29], especially in a context of restricted collaborative planning and under the influence of vested interests [30].

On one hand, an adequate consideration of specific environmental and institutional factors are needed to ease the implementation of the desired modifications within the system [31] [32]. In another hand, it is highlighted the need to gradually internalize SEA based on cumulated practical experience instead of beginning with the implementation of mandatory requirements in the first instance [27].

\section{Methods}

Based on exploratory and inductive approaches, the research has used both a single-case study and a qualitative content analysis. The case study was conducted based on guidance provided by [33], consisting of a critical case in which a change in the legal status of SEA has occurred, thus providing the opportunity to study the results (similar to other studies, e.g. [34]).

Data gathering was accomplished through qualitative content analysis following [35], which means a systematic and objective analysis of documents was applied to collect data and make valid inferences from specified characteristics within the text [35] [36].

\subsection{Object of Study: SEA Practice in the Democratic Republic of Congo (DRC)}

SEA practice in the Democratic Republic of Congo (DRC) was taken as an ex- 
ploratory single-case study. The DRC is located in Central sub-Saharan Africa with a population of more than 81 million and an area of 2,345,409 $\mathrm{km}^{2}$ [37] and is one of the few African countries with a formal SEA system being implemented (the legislation was approved in 2014). According to the Ministry of Environment (personal communication, January 15, 2016) DRC's experience with SEA practice consisted of 12 SEAs prepared since 2007.

Through an extensive search in Multilateral Development Agencies (MDA) databases and contact with the IA's professional community in the DRC, 10 SEAs were identified (Table 1). It is relevant to say that nine of these SEAs were required by MDAs, thus reinforcing the relevance of multilateral agencies to SEA dissemination and practice, as previously reported by [4] [38] [39].

Documentation (SEA reports, Summary report or the Term of Reference/ToR) was found to eight SEAs of different types/purposes, which were analyzed in this paper. It is important to highlight that the DRC lacks of an Environmental Agency and there is few national consultants, thus exacerbating the difficulty of accessing EA documents.

Table 1. SEAs from DRC, identified by the authors until 2016.

\begin{tabular}{|c|c|c|c|c|c|}
\hline & & Type of SEA & Setor & $\begin{array}{l}\text { Year of } \\
\text { completion }\end{array}$ & $\begin{array}{l}\text { Document } \\
\text { available }\end{array}$ \\
\hline 1 & $\begin{array}{l}\text { Nile Basin Initiative Institutional } \\
\text { Strengthening Project (Case A) }\end{array}$ & $\begin{array}{l}\text { Strategic/Sectoral, Social and } \\
\text { Environmental Assessment }\end{array}$ & Basin Management & 2007 & Report \\
\hline 2 & $\begin{array}{l}\text { Programme for preservation of } \\
\text { Congo Basin Ecosystems (Case B) }\end{array}$ & $\begin{array}{l}\text { Strategic Environmental } \\
\text { Assessment }\end{array}$ & Basin management & 2008 & $\begin{array}{l}\text { Summary } \\
\text { report }\end{array}$ \\
\hline 3 & $\begin{array}{l}\text { Multimodal Transport Project } \\
\text { (Case C) }\end{array}$ & $\begin{array}{l}\text { Sectoral Environmental } \\
\text { Assessment }\end{array}$ & Transport & 2008 & Report \\
\hline 4 & $\begin{array}{l}\text { National Programme of Forestry and } \\
\text { Nature Conservation (Case D) }\end{array}$ & $\begin{array}{l}\text { Strategic Environmental } \\
\text { Assessment }\end{array}$ & Forestry & 2008 & Report \\
\hline 5 & $\begin{array}{l}\text { Programme of Reduced Emissions } \\
\text { from Deforestation and Forest } \\
\text { Degradation (Case E) }\end{array}$ & $\begin{array}{l}\text { Strategic Environmental and } \\
\text { Social Assessment }\end{array}$ & $\begin{array}{l}\text { Agriculture, forests, } \\
\text { energy and employment }\end{array}$ & 2015 & Report \\
\hline 6 & $\begin{array}{l}\text { Project to support the Mining Sector } \\
\text { (Case F) }\end{array}$ & $\begin{array}{l}\text { Strategic Environmental and } \\
\text { Social Assessment }\end{array}$ & Energy and Mining & 2010 & ToR \\
\hline 7 & $\begin{array}{l}\text { Enhancing Institutional Capacities on } \\
\text { REDD }^{\star} \text { Issues for Sustainable Forest } \\
\text { Management in the Congo Basin } \\
\text { (Case G) }\end{array}$ & $\begin{array}{l}\text { Regional Environmental and } \\
\text { Social Assessment }\end{array}$ & $\begin{array}{l}\text { Forestry and Climate } \\
\text { Change }\end{array}$ & 2011 & ToR \\
\hline 8 & $\begin{array}{l}\text { Oil Exploration/Exploitation in the } \\
\text { north of Albertine Rift (Case H) }\end{array}$ & $\begin{array}{l}\text { Strategic Environmental } \\
\text { Assessment }\end{array}$ & Energy & 2013 & ToR \\
\hline 9 & $\begin{array}{l}\text { Africa-Shared Vision Program: 2nd } \\
\text { Phase Regional Power Trade Project }\end{array}$ & $\begin{array}{l}\text { Strategic Social and } \\
\text { Environmental Assessment }\end{array}$ & Energy & 2009 & Not found \\
\hline 10 & $\begin{array}{l}\text { Oil concession areas in and around } \\
\text { Virunga National Park }\end{array}$ & $\begin{array}{l}\text { Strategic Environmental } \\
\text { Assessment }\end{array}$ & Energy & In progress & - \\
\hline
\end{tabular}

${ }^{*}$ Reduced Emissions from Deforestation and Forest Degradation. 
Although the number of SEAs prepared in the RDC is virtually insignificant it should not be neglected. Currently, there is a growing number of developing countries which have little experience with SEA application [4] [28] and nonetheless have moved forward to the implementation of a SEA system [5]. Besides, according to [40], even with a limited number of SEAs there is a need to review the previous practice to learn from cumulated experience with the instrument, once there is always relevant lessons that could be valuable to the development of new regulations.

\subsection{The Practice of SEA in RDC in a Non-Regulated Context}

\section{- SEA report quality review}

The reason for examining SEA reports is to get a picture of the SEA process in DRC. In this case, four SEA reports and one summary report ${ }^{1}$ were reviewed (as indicated in Table 1) based on criteria developed by [2] [20] complemented by additional criteria derived from [41] [42] [43]. The final review package, presented in Box 1, consists of 7 sections sub-divided in 40 questions.

Although some of these criteria were inspired in the EU SEA Directive (42/ EC/2001) requirements, they reflect common good SEA practice [43] [44]. Furthermore, they have been already applied in non-EU contexts to review the quality of SEA reports (e.g., [45]).

Reports were reviewed using the grade system proposed by [2], within which the scores vary from A (task well performed with no important omissions) to $G$ (task not attempted at all) (Box 2). Criteria and sections were graded individually by at least 2 different reviewers and divergent grades were defined by consensus. Section grades are based on the overall picture emerging from individual grades, same approach used to attribute the grade to the overall report.

\section{- SEA ToR quality review}

Not all SEA reports needed to cover the purposes of the study were available (Table 1). In this case it was decided to analyze the ToRs emitted by MDAs, assuming that as they are SEA guiding documents they must provide a substantive overview of the assessment to be conducted [48].

A tool was specifically designed to review the quality of 3 ToRs (Box 3), based on existent guidelines to ToR development [49] [50] [51] and quality evaluation checklists applied to ToRs [48]. Due to certain features of ToRs, it was needed to redefine the descriptions of sections and criteria in order to allow for a review of the DRC ToRs guided by best practice principles. Although the review of ToRs may be seen as problematic because it is unusual in scientific literature, their evaluation enabled a more comprehensive analysis of SEA practice in the DRC.

ToRs were reviewed on the basis of the expected content of SEA (Box 4), following a simplified qualitative scoring system adapted from [52] [53] [54]. Sections and the overall ToR were evaluated individually according to whether the whole picture emerging from individual grades was fully, partly or not met at all. ${ }^{1}$ Summary reports have been used as source of information in quality review studies. According to [46], a summary report has to adequately represent the main report emphasizing its major findings and, therefore, it is expected to meet the criteria applied in quality reviews. 
Box 1. SEA report review criteria.

\section{Evaluation guide}

Section 1: strategic action and environmental baseline description, strategic action and SEA process integration

1 Contents and main objectives of the strategic action are outlined.

2 Relationship with other relevant strategic actions are outlined.

3 SEA objectives are outlined.

4 How the SEA was conducted is described.

How SEA and strategic action making processes were integrated (i.e. SEA should take place during strategic action preparation and before its adoption or submission to the legislative procedure) is described.

6

With a view to avoid duplication of assessment, the report describes what issues are addressed in other assessments, i.e. at other levels/layers within a planning system/hierarchy.

The report provides information on the relevant aspects of the current state of the environment, economy and social aspects likely to be significantly affected and the likely evolution thereof without implementation of the strategic action.

The report provides information on any existing environmental/sustainability problems that are relevant to the strategic action including, in particular, those relating to any areas of particular environmental importance.

The report provides information on environmental protection objectives, established at international, African or DRC

9 level, which are relevant to the strategic action and the way those objectives and any environmental considerations have been taken into account during its preparation.

\section{Section 2: Identification and evaluation of key issues and options}

10 How reasonable alternatives were identified, considering objectives and geographical scope of the strategic action is descrived.

11 Environmental issues considered in assessment are listed.

12 The report describes how environmental issues considered in assessment were identified.

The report provides information on the likely significant effects of different options on: 1) biodiversity, 2) population,

13 3) human health, 4) fauna, 5) flora, 6) soil, 7) water, 8) air, 9) climatic factors, 10) material assets, 11) cultural heritage, including architecture and archaeology, 12) landscape, 13) the interrelationship between the above factors.

Matters more appropriately assessed at other levels or layers of decision-making, with a view to avoid duplication, are provided.

15 The report shows how state-of-the-art knowledge and methods of assessment were used.

16 The assessment focuses on significant issues and disregards less significant ones. Reasons for eliminating issues from further consideration are documented.

\section{Section 3: Determination of impact significance}

The assessment identifies the degree to which the strategic action sets a framework for project/other activities, either in terms of location, size, nature and operating conditions or by allocating resources.

The assessment identifies value and vulnerability of the area likely to be affected due to special natural characteristics or cultural heritage, exceeded environmental quality standards, exceeded limit values or intensive land use.

The report refers to the strategic action effects on areas or landscapes that have a recognized DR Congolese, African or international protection status of the various options.

The probability, duration (short, medium and long term, permanent and temporary), frequency and reversibility of effects (both positive and negative) of the various options are identified.

21 The secondary, cumulative and synergistic nature of the effects of the various options are identified.

22 The transboundary nature of the effects of the various options are identified.

23 Risks to human health and the environmental issues (e.g. due to accidents, of various options) are identified.

24 The magnitude and spatial extent of the effects (geographical area and size of population affected) of the various options 


\section{Continued}

\section{Section 4: Consultation process}

The report describes how authorities were consulted when scope and level of detail of information in assessment were identified.

The report describes how the draft strategic action and environmental report were made available to authorities and the public likely to be affected or having an interest in the strategic action and were allowed to express their opinions within an appropriate time frame.

27

The report refers to the confirmation that consultation results on strategic action and SEA are to be considered in decision-making.

\section{Section 5: Presentation of information and results}

The report includes a clearly distinguishable SEA section or there is a separate environmental report .

Information on any difficulties (such as technical deficiencies or lack of know-how) and uncertainties encountered in compiling the required information is provided.

Once a decision has been made, is accompanied by a statement summarizing how environmental/sustainability considerations have been integrated into the strategic action and how the environmental report and the results of the consultations have been taken into account and the reasons for choosing the strategic action as adopted in the light of the other reasonable alternatives dealt with.

31 Strategic actions conflicts and how to reconcile the strategic actions in order to promote sustainability are reported.

\section{Section 6: Recommendations on preferred options and monitoring}

32 The report outlines the reasons for selecting the alternatives dealt with, and a description of how the assessment leading to these reasons was undertaken.

33

Information on the measures envisaged to prevent, reduce and as fully as possible offset any significant adverse effects on the environment of implementing the strategic action is provided.

34

The report describes the measures envisaged concerning monitoring of the significant environmental effects of the strategic action implementation in order, inter alia, to identify at an early stage unforeseen adverse effects.

35 How monitoring is done, in order to be able to undertake appropriate remedial action is explained.

36 The report explains how existing monitoring arrangements may be used, if appropriate, in order to avoid duplication.

\section{Section 7: SEA report}

37 The report is clear and concise in its layout and presentation, is presented as an integrated whole, and uses maps and other illustrations where appropriate.

38 The language is simple, clear and technical jargon is avoided.

39 The methodology used in the SEA is described.

40 The report is written without bias in an impartial and open manner.

Source: based on [2] [20] [41] [42] [43].

Box 2. Report scoring system.

Grade A-Task well performed with no important omissions.

Grade B-Task satisfactorily performed and complete with only minor omissions/ inadequacies.

Grade C-Satisfactory despite some important omissions or inadequacies.

Grade D-Task well attempted but, on the whole, unsatisfactory because of omissions or inadequacies.

Grade E-Unsatisfactory, task attempted with significant omissions or inadequacies.

Grade F-Very unsatisfactory with important tasks badly attempted.

Grade G-Task not attempted at all.

Source: [2], based on [47]. 
Box 3. ToR review criteria.

\section{Section 1: SEA Title}

1 The SEA title stated in the ToR is short, descriptive and easily remembered.

2 The SEA title connects well with the strategic action that is being assessed.

3 A general strategic action description and strategic action rationale is provided.

\section{Section2: SEA Purpose}

4 The current purpose, objectives, and intended outcomes of the strategic action being evaluated are described.

5 The reason to undertake the SEA and expected outcomes are specified.

The SEA objectives are realistic and achievable, in light of the information that can be collected in the context of the undertaking.

7 The ToR mentions who requires the SEA results and what they will do with them.

8 The mandate for the conduct of the SEA is referenced.

\section{Section 3: SEA Context}

9

The ToR adequately describes the particular political, programmatic and governance environment in which the SEA will be taking place. The most relevant aspects of the economic, social, environmental and political context are described.

10 A summary of the main stakeholders involved in the Strategic action is provided.

11 The legislative basis for the proposed strategic action (all relevant and applicable international/regional laws, standards, and guidelines) is outlined.

\section{Section 4: SEA Scope}

12

What will and will not be covered, including, for example, the timeframe and/or geographical area to be covered by the SEA is explicitly and clearly defined.

13 The scope of the SEA is adequate to meet its stated objective(s).

14 The scope of the SEA is feasible given resources and time considerations.

15 A list of written material that the SEA team should refer to as part of the SEA is provided.

16 Standard limits to be adopted are provided.

\section{Section 5: Environment, Impacts and Mitigation}

17 Assessment of the potential and probable environmental impacts associated with the proposed strategic action is required.

18 Mitigation and monitoring of the negative impacts of the proposed strategic action are required.

\section{Section 6: Strategic action Alternatives}

19

Consideration of at least two alternatives- "no development" and "strategic action alternative" options-to the proposed strategic action is required.

\section{Section 7: SEA Work Plan}

20 Outputs that will be delivered by the SEA team, including information on the degree to which the SEA report will be accessible to stakeholders are stated.

21 Key stages of the SEA process and the strategic action time line are described.

22 The adequate level of detail of the SEA is outlined.

23 Attributes (skills and experience) and responsibilities of the SEA team are listed.

Sources: [48] [49] [50] [51] [54]. 
Box 4. ToR scoring system.

Response for each criterion had three possible answers:

$(\sqrt{ })$ Meets requirements: the answer to the criterion is fully and unambiguously positive. There is no important omissions observed and no doubt about the response. The reviewer quickly perceives that the response is affirmative.

$(\approx)$ Partially meets requirements: the response to the criterion is not easily understood, or the reviewer is left with doubts about the answer.

$(\chi)$ Does not meet requirements: the response to the criterion is totally and unequivocally negative.

Sources: See text.

\subsection{The SEA System Introduced in RDC by the New Legislation}

The context of SEA in the RDC is currently set out by two regulations promulgated in 2011 and 2014, respectively, namely the Environment Protection Act No. 11/009 (EPA) and the Environmental Minister Decree No. 14/019. Based on these documents, the framework of the DCR SEA system was described focusing on the characteristics of the assessment process and the involved stakeholders.

In order to get a better picture of the SEA process as a whole based on an international perspective, this framework was then assessed against international principles of SEA effectiveness (Box 5), which has been widely used to examine the effectiveness of SEA in different contexts [55] [56] [57] [58]. Once again following [53] a 3-level assessment grades was applied (Box 6).

\section{Results and Discussion}

\subsection{SEA Practice before Its Transposition into National Legislation: SEA Report and ToR Quality Review}

Table 2 shows the results of the quality review of SEA reports. Only two out of five SEA reports reviewed in this paper were deemed a satisfactory quality. The main weaknesses of SEA in DRC practice are related to the determination of impact significance (criteria 17, 20 and 21), consultation process (criterion 27) and recommendations on the preferred alternatives and monitoring (criteria 35 and 36). By contrast, reports showed good quality when documenting baseline, strategic actions and SEA processes integration (criteria 1 and 9), and the SEA report layout (criteria 37, 38, 39 and 40).

Regarding ToRs quality review, the results are presented in Table 3. None of the three ToRs was deemed a fully satisfactory quality, indicating that the whole picture emerging from individual grades was not fully met. Very few of the ToRs adequately refer to the identification of standard limits (criteria 16), approaches to mitigate and monitor the negative impacts of the proposed strategic action (criteria 18) and consideration of alternatives (criterion 19). However, most of ToRs have an explicit consideration of the SEAs titles (criteria 2 and 3), description of main stakeholders involved in the strategic action (criterion 10), relevant and applicable legislations (criterion 11), scope of the SEA (criteria 14 and 15), outputs to be delivered by the SEA team (criterion 20), and responsibilities as well as skills and experience of the SEA team (criterion 23). 
Box 5. International principles of SEA effectiveness.

\begin{tabular}{|c|c|}
\hline Is integrated & $\begin{array}{l}\text { Ensures an appropriate environmental assessment of all strategic decisions relevant for the achievement of } \\
\text { sustainable development. } \\
\text { Addresses the interrelationships of biophysical, social and economic aspects. } \\
\text { Is tiered to policies in relevant sectors and (transboundary) regions and, where appropriate, to project EIA } \\
\text { and decision making. }\end{array}$ \\
\hline Is sustainability-led & Facilitates identification of development options and alternative proposals that are more sustainable. \\
\hline Is focused & $\begin{array}{l}\text { Provides sufficient, reliable and usable information for development planning and decision-making. } \\
\text { Concentrates on key issues of sustainable development. } \\
\text { Is customized to the characteristics of the decision making process. } \\
\text { Is cost- and time-effective. }\end{array}$ \\
\hline Is accountable & $\begin{array}{l}\text { Is the responsibility of the leading agencies for the strategic decision to be taken. } \\
\text { Is carried out with professionalism, rigor, fairness, impartiality and balance. } \\
\text { Is subject to independent checks and verification. } \\
\text { Documents and justifies how sustainability issues were taken into account in decision making. }\end{array}$ \\
\hline Is participative & $\begin{array}{l}\text { Informs and involves interested and affected public and government bodies throughout the decision making } \\
\text { process. } \\
\text { Explicitly addresses their inputs and concerns in documentation and decision-making. } \\
\text { Has clear, easily-understood information requirements and ensures sufficient access to all relevant } \\
\text { information. }\end{array}$ \\
\hline Is iterative & $\begin{array}{l}\text { Ensures availability of the assessment results early enough to influence the decision making process and } \\
\text { inspire future planning. } \\
\text { Provides sufficient information on the actual impacts of implementing a strategic decision, to judge whether } \\
\text { this decision should be amended and to provide a basis for future decisions. }\end{array}$ \\
\hline \multicolumn{2}{|c|}{ Source: Intermational Association for Impact Assessment. } \\
\hline \multicolumn{2}{|c|}{ Box 6. Regulation ratings key. } \\
\hline \multicolumn{2}{|c|}{$\sqrt{ }$ criteria satisfactorily met. } \\
\hline \multicolumn{2}{|c|}{$\approx$ criteria partially met. } \\
\hline $\begin{array}{l}\chi \text { criteria not met. } \\
\text { ? could not be evalua }\end{array}$ & ated in this study. \\
\hline
\end{tabular}

Common weaknesses were observed in SEA reports and ToRs, thus reinforcing the relevance of the scoping stage. Omissions and deficiencies include the lack of information regarding how reasonable alternatives were identified (Cases $\mathrm{B}$ and $\mathrm{C}$ ) and how the preferred alternative was defined (Case D). These findings are similar to what was previously reported to other contexts, such as the transport sector in New Zealand (non mandatory context) [59] and spatial plan core strategy SEAs in England (mandatory context) [20]. 
Table 2. Reports quality review scores.

\begin{tabular}{|c|c|c|c|c|c|c|}
\hline SEAs & & Case A & Case B & Case C & Case D & Case $\mathrm{E}$ \\
\hline \multirow{9}{*}{ Section 1: SEA Title } & S1C1 & & & & & \\
\hline & $\mathrm{S} 1 \mathrm{C} 2$ & & & & & \\
\hline & S1C3 & & & & & \\
\hline & S1C4 & & & & & \\
\hline & S1C5 & & & & & \\
\hline & S1C6 & & & & & \\
\hline & S1C7 & & & & & \\
\hline & S1C8 & & & & & \\
\hline & S1C9 & & & & & \\
\hline \multirow{7}{*}{ Section2: SEA Purpose } & $\mathrm{S} 2 \mathrm{C} 10$ & & & & & \\
\hline & $\mathrm{S} 2 \mathrm{C} 11$ & & & & & \\
\hline & $\mathrm{S} 2 \mathrm{C} 12$ & & & & & \\
\hline & $\mathrm{S} 2 \mathrm{C} 13$ & & & & & \\
\hline & S2C14 & & & & & \\
\hline & S2C15 & & & & & \\
\hline & $\mathrm{S} 2 \mathrm{C} 16$ & & & & & \\
\hline \multirow{8}{*}{ Section 3: SEA Context } & S3C17 & & & & & \\
\hline & S3C18 & & & & & \\
\hline & S3C19 & & & & & \\
\hline & S3C20 & & & & & \\
\hline & S3C21 & & & & & \\
\hline & S3C22 & & & & & \\
\hline & S3C23 & & & & & \\
\hline & S3C24 & & & & & \\
\hline \multirow{3}{*}{ Section 4: SEA Scope } & S4C25 & & & & & \\
\hline & S4C26 & & & & & \\
\hline & S4C27 & & & & & \\
\hline \multirow{2}{*}{$\begin{array}{l}\text { Section 5: Environment, } \\
\text { Impacts and Mitigation }\end{array}$} & S5C28 & & & & & \\
\hline & S5C29 & & & & & \\
\hline
\end{tabular}




\section{Continued}

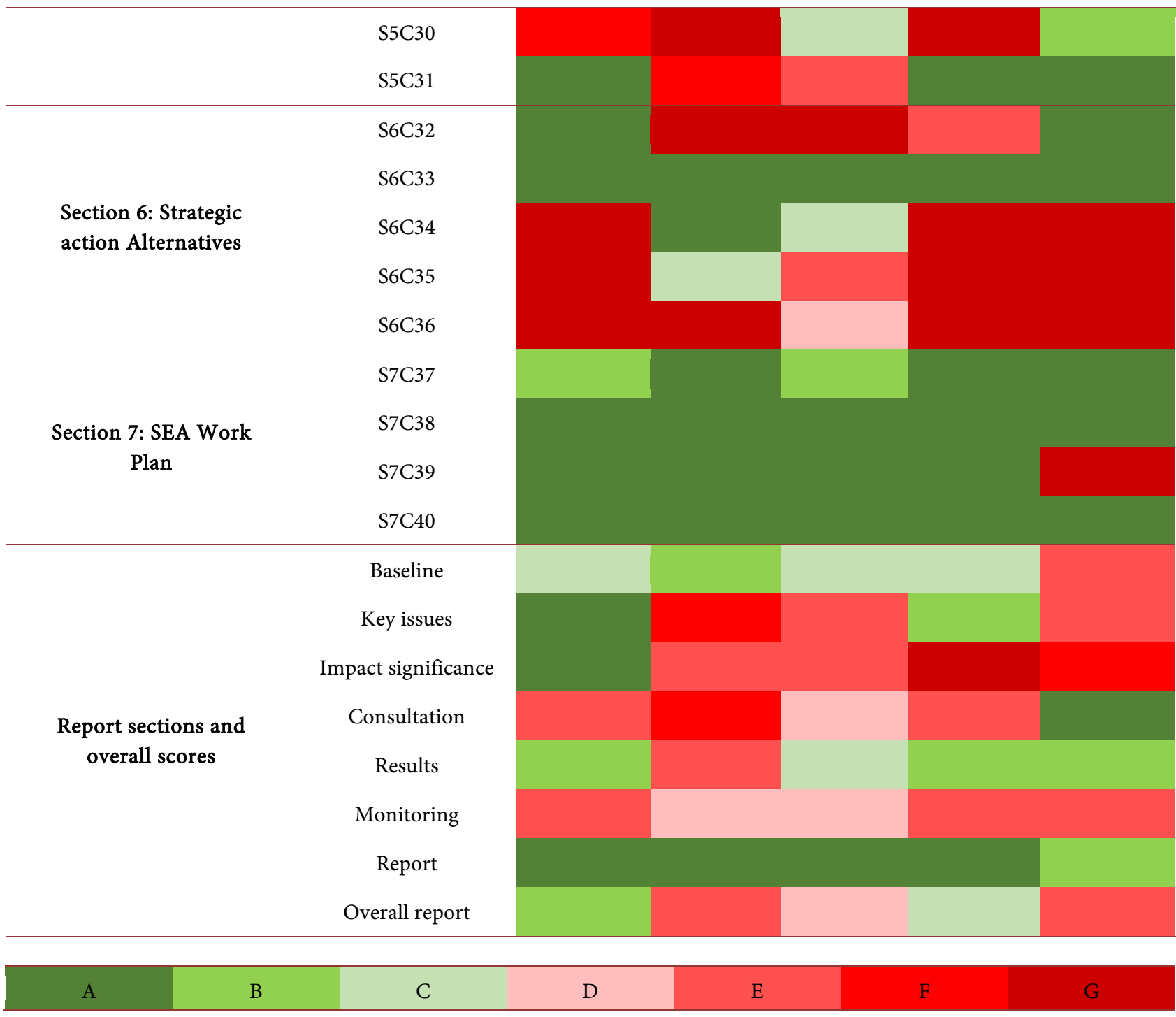

Table 3. ToRs quality review scores.

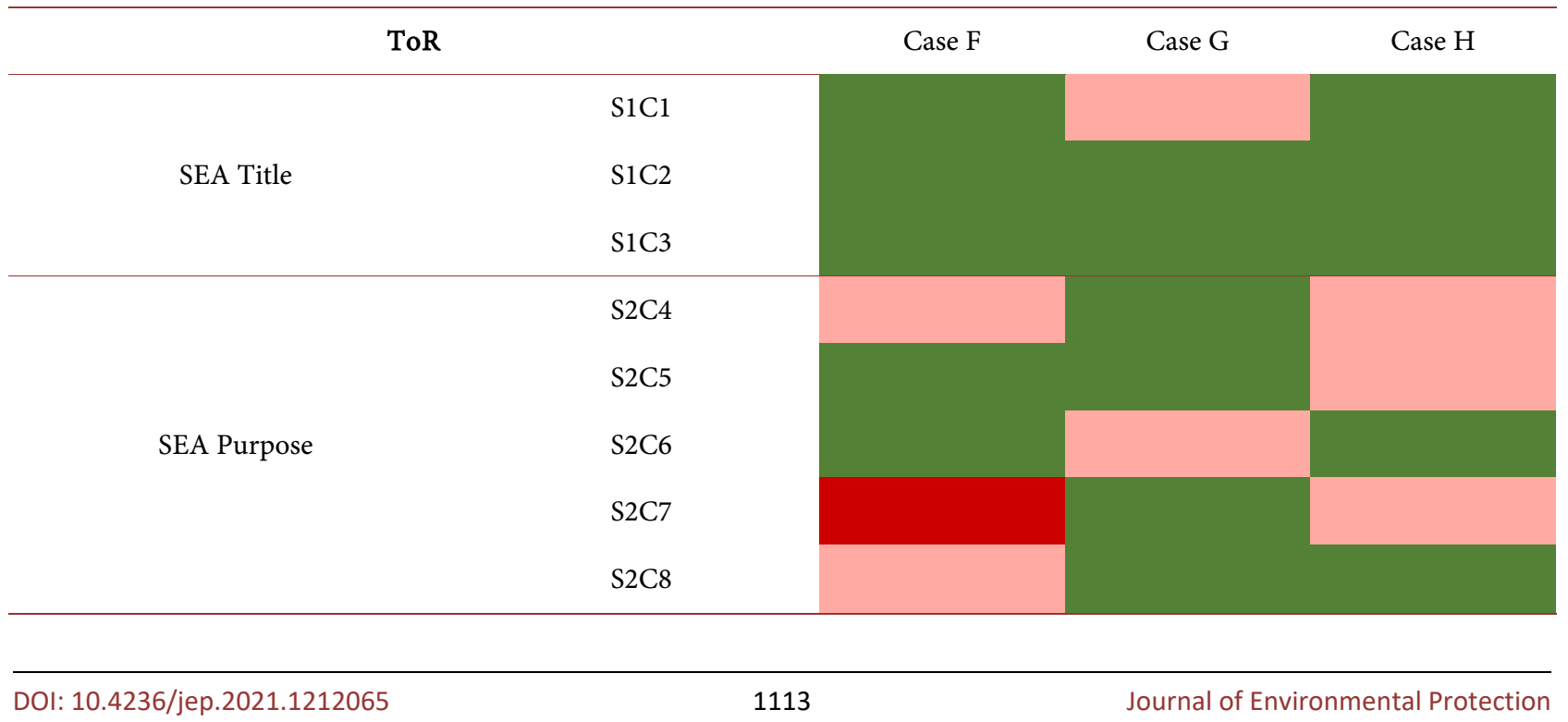




\section{Continued}

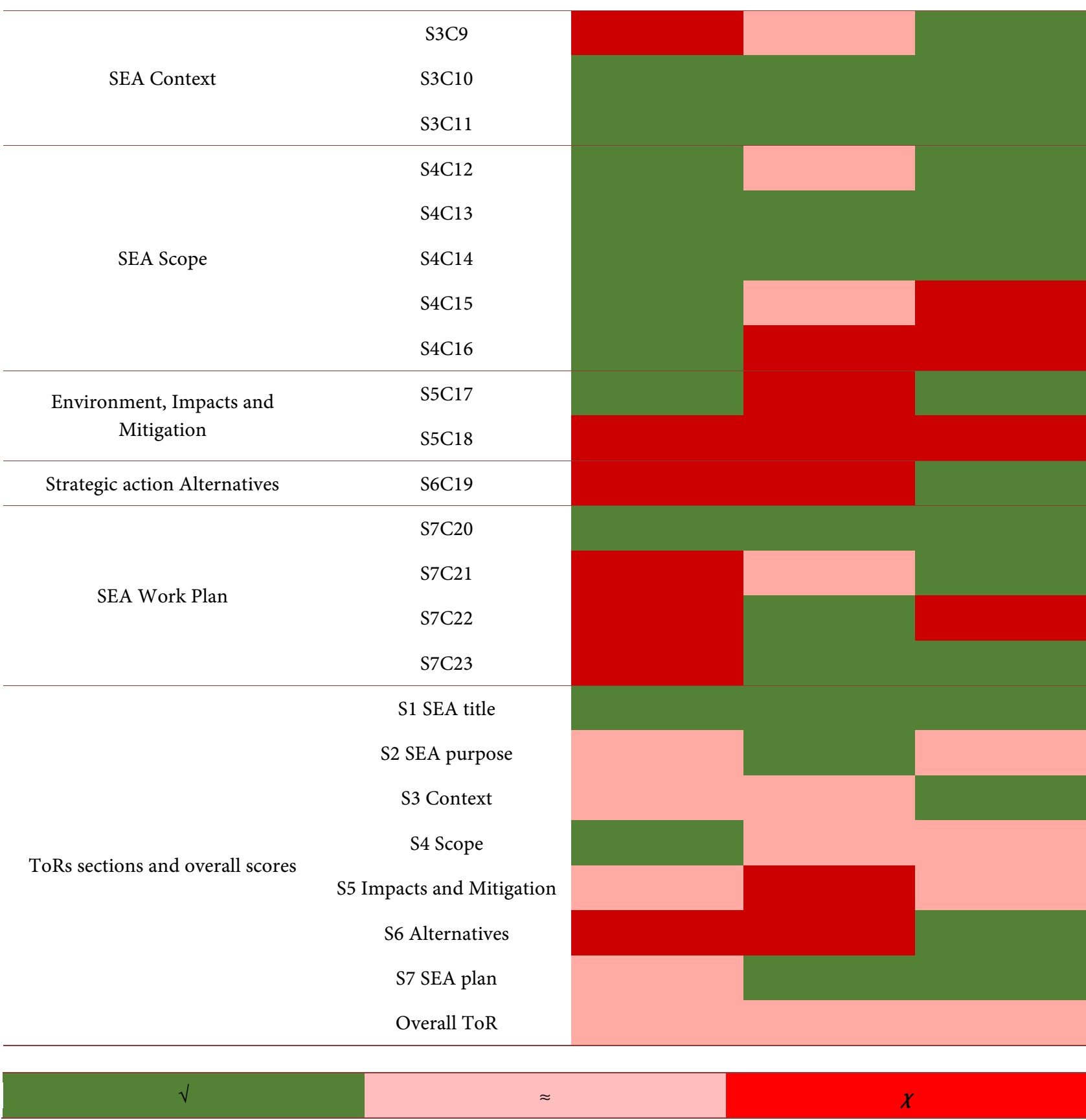

Adequate development of alternatives constitutes a major concern in both developed and developing countries [11] [20] [60]. Since it is acknowledged that the identification and development of alternatives is a recognized challenge to SEA effectiveness [61], it would be desirable to ensure best practicable environmental options are chosen.

The lack of information on approaches to monitoring impacts was also found to be a significant shortcoming of DRC's SEA. None of SEA reports and ToRs have explicitly considered monitoring arrangements. Only one case (case C) referred to the use of existing monitoring arrangements as a proxy, suggesting the 
institutions responsible for this task. This aspect has showed to be relevant to improve SEA's effectiveness in DRC, given the role monitoring can play in strengthening the quality of the whole SEA process [62].

Added to this, the weak performance of ToR in guiding the scope and content of the assessment may be hindering SEA effectiveness.

\subsection{SEA Transposition into National Legislation: Characteristics and Performance}

\section{- Characterizations of DRC SEA legislation}

After many years in draft form, a framework for environment assessment was promulgated: the Environmental Protection Act (EPA), No. 11/009 of the $9^{\text {th }}$ of July, 2011. It contains several new requirements, notably the obligation to undertake an environmental and social impact study; environmental audits; environmental evaluation of PPPs; the creation of new institutional structures; and an Environmental Fund for research, conservation, clean-up operations, rehabilitation and pollution prevention (Article 25).

The EPA establishes environmental assessments to be undertaken during planning process conducted by the state, provinces and other decentralized territorial entities (Article 6). It requests the consideration of the imperatives of environmental protection and the wellbeing of local population during the preparation of land use management and zoning plans, including urban plans.

In Article 2, it defines environmental assessment of PPP as a tool, which aims to systematically assess environmental issues at strategic level. According to the law (article 19), all public strategic actions, which may have a significant environmental impact, are subject to prior environmental evaluation. The term "Strategic Environmental Assessment" is not adopted in the EPA, but was first presented in the Environmental Minister Decree (EMD) No. 14/019 of the $2^{\text {nd }}$ of August, 2014, which named the environmental assessment of PPPs as "Strategic Environmental Assessment" and established the operational rules to this instrument (Article 1). A set of activities and sectors subject to SEA is listed: infrastructure, hydrocarbons, mining, energy, telecommunication, industry, land use, forestry, agriculture, fishery, urbanism and habitat, transport, rural development, tourism and hospitality, education, health and any other commercial activities that may have an impact on the environment (Article 4).

According to the Decree, the DRC Environmental Agency should grant a compulsory Environmental Notice for the implementation of PPPs, so the beneficiary must comply with the principles of environmental and social safeguards stated in Article 15. Figure 1 summarizes the procedure for obtaining the environmental notice.

Figure 2 presents the content of SEA report as stablished by the Decree, which has three main parts including screening, scoping and the proper SEA. Figure 2 also presents the steps of each part. It is to be noted that the Decree points these steps without providing their meanings and/or the information to be provided in each of them. 


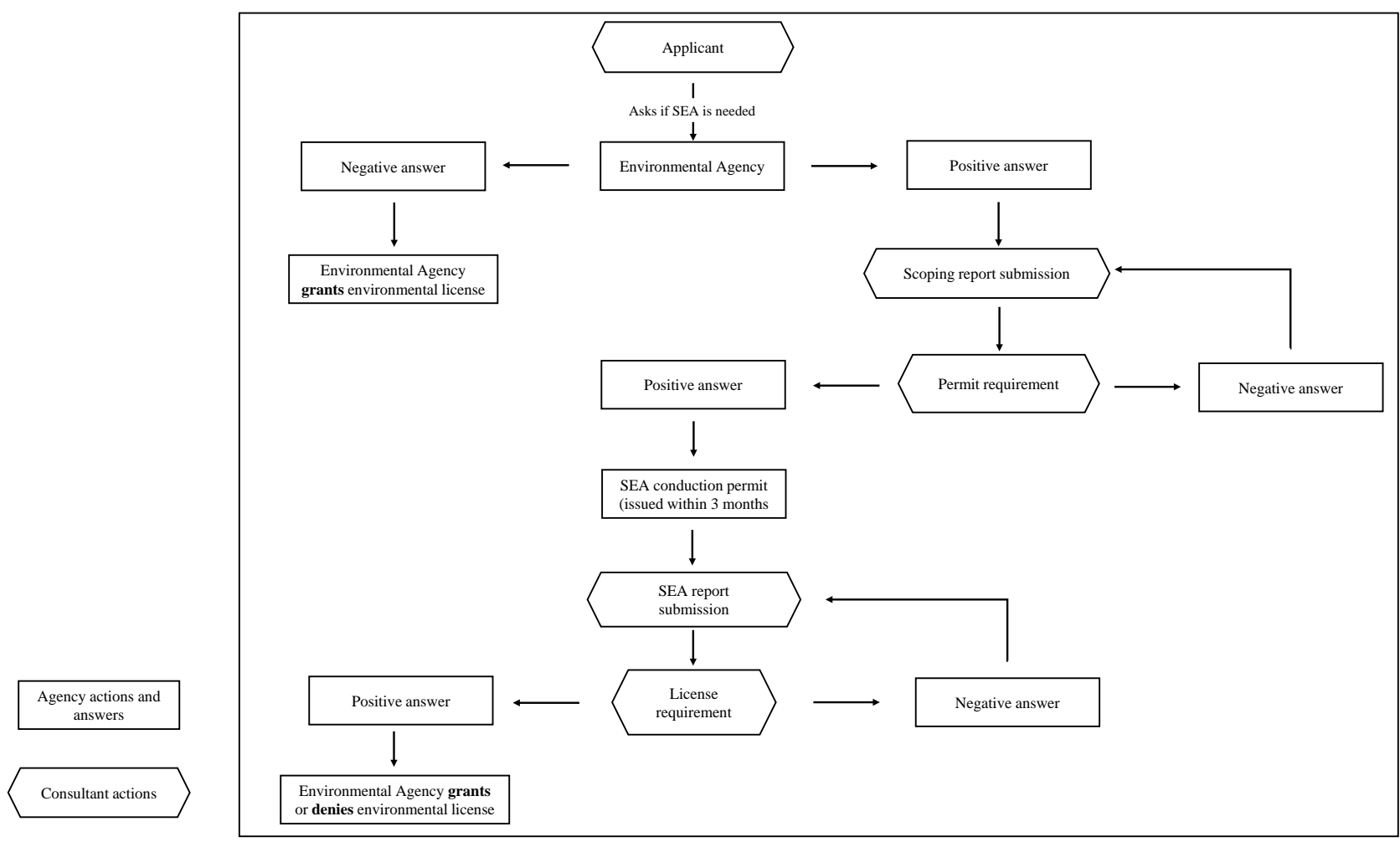

Figure 1. Procedure for obtaining environmental notice according to the EMD No. 14/019 of the 2nd of August, 2014. Source: based on Environmental Minister Decree No. 14/019 of the 2nd of August, 2014.

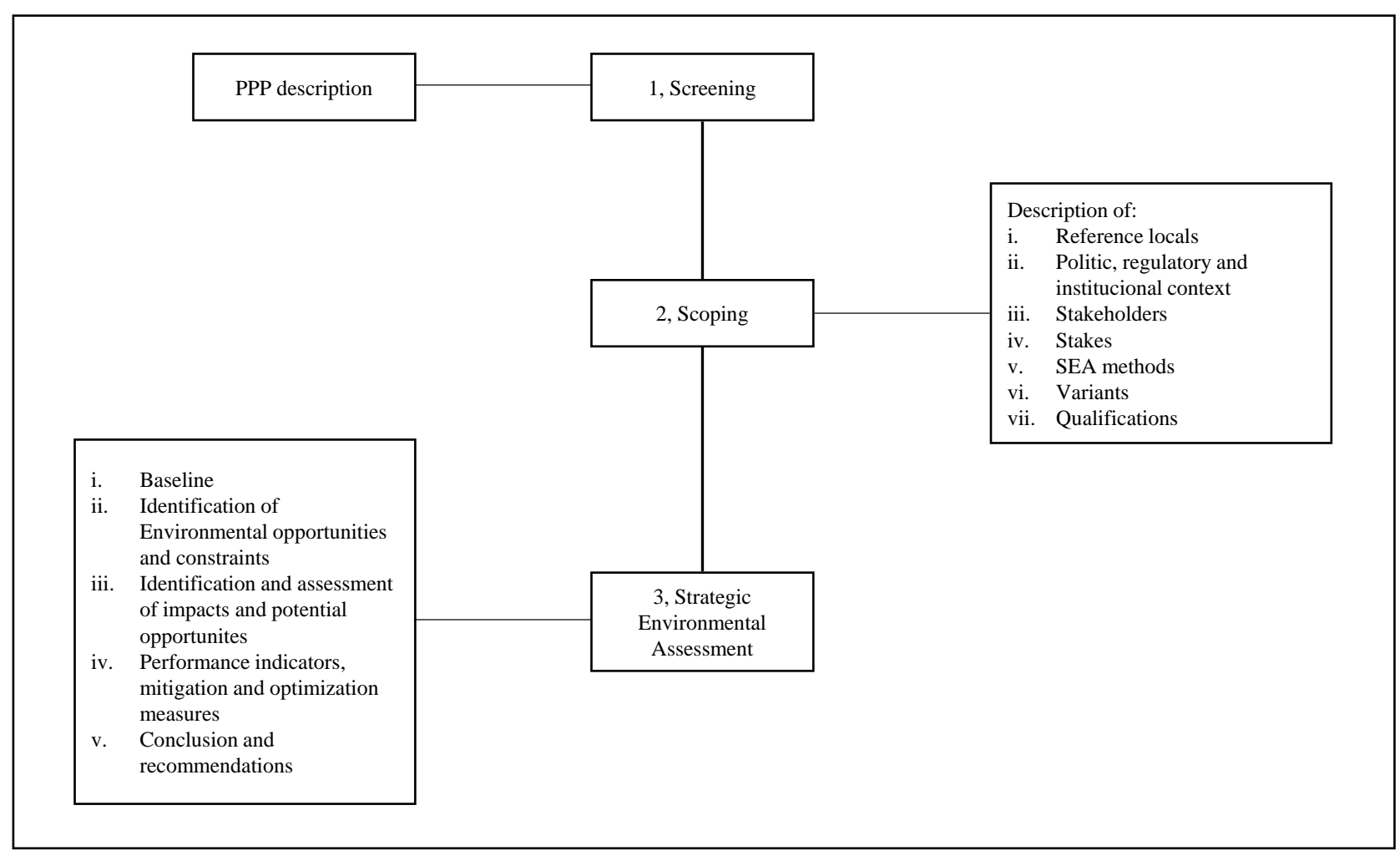

Figure 2. Content of SEA based on Environmental Minister Decree No. 14/019 of the 2nd of August, 2014. Source: based on Environmental Minister Decree No. 14/019 of the 2nd of August, 2014. 
The Decree also states that the assessment has to be conducted by a national or international consultant accredited by the Ministry of Environment (Article 10 ), and makes provision for regulations to be made regarding institutions involved, content of the SEA report, guidelines for various stages of the SEA process, sectors concerned and the review process.

\section{- Regulation evaluation against international SEA performance criteria}

Results of SEA system evaluation against international SEA performance criteria are summarized in Table 4. Ratings were based on qualitative evaluation; the table's footnotes present justifications for the ratings. According to the findings, the new DRC SEA system is far from fulfilling its potential to enable more effective environmental assessment at PPP level.

Broadly speaking, SEA can be considered time-consuming in the DRC. According to [43] (p. 208) "a typical, reasonably brief and efficient SEA might take 50 - 100 person-days". However, the whole process is accepted to run in 18 months. The EMD requires a SEA scoping report to be provided by the consultant. The environmental agency has up to three months to check the conformity of this document. If needed, the consultant will be notified to rectify the scoping report within three months. Once again, the environmental agency has up to three months to decide on the conformity of the corrected scope report and grant the environmental notice. Only then the SEA process is allowed to proceed, following a similar timeframe to the final SEA report. There is obviously a need to overcome time constraints, once time is a major concern of all SEA systems in terms of cost [63] and, presumably more relevant, in terms of the restrictions posed to future developments [64].

Public consultation is another main concern of the DRC SEA system. The role of public consultation in promoting accountability and transparency of the decision-making process is largely recognized in the literature [65] [66] [67]. However, whilst the EPA (Art 9) requires public involvement in any decision-making process, the Decree does not make provisions for any type of formal consultation at higher decision-making levels.

Also, similar to what was reported by [43] regarding the European Union's SEA Directive (2001/42/EC), many aspects of the DRC regulations remain to be interpreted and consolidated, and perhaps this will have to wait until specific cases emerge requiring court decisions or through the cumulated experience and learning from SEA practice.

A clear strength of the SEA system is the provision to integrate SEA and PPPs development in order to provide information early enough, preferably in a moment in which the recommendations could still be considered relevant to modify the strategic actions. This is relevant, according [65], once planning and SEA processes should run in a way that allows interaction between stakeholders, an adequate SEA timing and diffusion of results linked to the needs of decision-makers.

\subsection{DRC SEA Procedures against SEA Early Practice}

Table 5 summarizes the comparison of SEA practice before its transposition into 
national legislation and the new SEA system.

Findings from the quality review indicate that screening, scoping, mitigation and report were explicitly addressed before SEA transposition into the DRC

Table 4. DRC SEA legislation evaluated against IAIA's performance criteria.

\begin{tabular}{|c|c|c|}
\hline \multicolumn{2}{|c|}{ IAIA SEA performance criteria } & \multirow{2}{*}{$\begin{array}{l}\text { Rating } \\
\approx^{(\mathrm{a})}\end{array}$} \\
\hline & $\begin{array}{l}\text { Ensures an appropriate environmental assessment of all strategic decisions relevant for the } \\
\text { achievement of sustainable development. }\end{array}$ & \\
\hline \multirow[t]{2}{*}{ Is integrated } & Addresses the interrelationships of biophysical, social and economic aspects. & $\chi^{(\mathrm{b})}$ \\
\hline & $\begin{array}{l}\text { Is tiered to policies in relevant sectors and (transboundary) regions and, where appropriate, to project } \\
\text { EIA and decision making. }\end{array}$ & $\approx(c)$ \\
\hline $\begin{array}{l}\text { Is } \\
\text { sustainability-led }\end{array}$ & Facilitates identification of development options and alternative proposals that are more sustainable. & $\approx(\mathrm{d})$ \\
\hline \multirow{4}{*}{ Is focused } & Provides sufficient, reliable and usable information for development planning and decision-making. & $\sqrt{ }(\mathrm{e})$ \\
\hline & Concentrates on key issues of sustainable development. & $\chi^{(\mathrm{f})}$ \\
\hline & Is customized to the characteristics of the decision making process. & $\sqrt{ }(\mathrm{g})$ \\
\hline & Is cost- and time-effective. & $? \chi^{(\mathrm{h})}$ \\
\hline \multirow{4}{*}{ Is accountable } & Is the responsibility of the leading agencies for the strategic decision to be taken. & $\sqrt{ }(\mathrm{i})$ \\
\hline & Is carried out with professionalism, rigor, fairness, impartiality and balance. & $?$ \\
\hline & Is subject to independent checks and verification. & $\sqrt{ }(\mathrm{j})$ \\
\hline & Documents and justifies how sustainability issues were taken into account in decision making. & $\chi^{(\mathrm{k})}$ \\
\hline \multirow{3}{*}{ Is participative } & $\begin{array}{l}\text { Informs and involves interested and affected public and government bodies throughout the decision } \\
\text { making process. }\end{array}$ & $\approx^{(1)}$ \\
\hline & Explicitly addresses their inputs and concerns in documentation and decision-making. & $\chi^{(\mathrm{m})}$ \\
\hline & $\begin{array}{l}\text { Has clear, easily-understood information requirements and ensures sufficient access to all relevant } \\
\text { information. }\end{array}$ & $\chi^{(\mathrm{n})}$ \\
\hline \multirow{2}{*}{ Is iterative } & $\begin{array}{l}\text { Ensures availability of the assessment results early enough to influence the decision making process } \\
\text { and inspire future planning. }\end{array}$ & $\sqrt{ }(\mathrm{o})$ \\
\hline & $\begin{array}{l}\text { Provides sufficient information on the actual impacts of implementing a strategic decision, to judge } \\
\text { whether this decision should be amended and to provide a basis for future decisions. }\end{array}$ & $\approx(\mathrm{p})$ \\
\hline
\end{tabular}

(a)The EPA (art 2, 19 and 20) requires the application of SEA to PPPs. The EMD (Art 3 and 4) indicates sectors subject to SEA. However, none of them refers to the achievement of sustainable development. ${ }^{(b)}$ No mention of any kind of interrelationships of biophysical, social and economic aspects. ${ }^{(c)}$ Tiered to decision-making and policies in relevant sectors (EMD Art 3 and 4). No reference of tiering with EIA. ${ }^{(\mathrm{d})}$ The EMD (Art 5c) only refers to alternatives as one of DRC SEA steps. However, there is no reference to sustainability. ${ }^{(\mathrm{e})}$ The EMD (Art $5 \mathrm{~b}$ and $\mathrm{c}$ ) refers to the report content, which includes, amongst other, baseline description; strategic action challenges, mitigation measures and, environmental opportunities and constraints. ${ }^{(f)}$ No mention of focus on key issues of sustainable development. ${ }^{(\mathrm{g})}$ The EMD (chapter 4) describes the step by step of the decision-making process. The Environmental agency has to guide consultants to ensure the conformity of the SEA scope and final report (EMD Art 11). ${ }^{\text {(h) }}$ The cost of the SEA could not be evaluated in this study. Regarding the time effectiveness, the whole SEA process lasts 9 to more than 18 months (EMD Art 11, 12, 13 and 14). ${ }^{(i)}$ The State, province, territorial entity or public institution is responsible for its strategic decision to be taken. ${ }^{\left({ }^{j}\right)}$ The environmental agency is responsible for checking the final report (EMD chapter 4). ${ }^{(\mathrm{k})}$ No requirement to justify how sustainability issues were taken into account in decision-making. ${ }^{(1)}$ The EPA (Art 9) requires the public involvement in the SEA process. However, the EMD does not request formal consultation for SEA. ${ }^{(\mathrm{m})}$ No requirement to address stakeholders inputs and concerns. ${ }^{(\mathrm{n})}$ No requirement about quality and access to information. ${ }^{(\mathrm{o})}$ SEA has to be conducted during planning

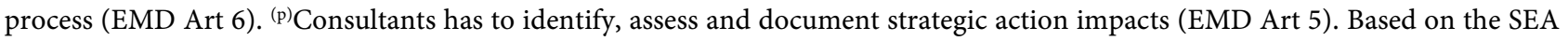
outcomes, the Environmental Agency judges whether the decision should be amended. However, there is no provisions for future decisions. 
Table 5. Comparison matrix.

\begin{tabular}{|c|c|c|}
\hline SEA Process Principles & Before SEA transposition into national legislation & DRC SEA system \\
\hline $\begin{array}{l}\text { Screening procedure } \\
\text { (taking into account } \\
\text { objectives and targets) }\end{array}$ & $\begin{array}{l}\text { Nine SEAs were required by Multilateral Development } \\
\text { Agencies (including World Bank, African Development } \\
\text { Bank) and development partners (from European Union) } \\
\text { that already have provisions for screening. One SEA was } \\
\text { conducted voluntarily. }\end{array}$ & $\begin{array}{l}\text { SEA applied to all public PPPs (EPA } \\
\text { Article } 19 \text { and 20; EMD article } 3 \text { and } 4 \text { ). } \\
\text { The Environmental Agency decides on the } \\
\text { need for a SEA (EMD article } 6 \text { and 10). No } \\
\text { SEA has been conducted under the new } \\
\text { legislation. }\end{array}$ \\
\hline Scoping & Satisfactory although parts are not well attempted. & $\begin{array}{l}\text { Has clear requirements for scoping. A } \\
\text { scoping report has to be submitted to the } \\
\text { Environmental Agency (EMD article } 8 \text { and } \\
\text { 12). }\end{array}$ \\
\hline $\begin{array}{l}\text { Consideration of } \\
\text { alternatives }\end{array}$ & Unsatisfactory. Poorly attempted. & $\begin{array}{l}\text { Requires scenario analysis without specific } \\
\text { information about the type of scenarios to } \\
\text { be taken into account (EMD article } 5 \mathrm{~b} \text { ). }\end{array}$ \\
\hline $\begin{array}{l}\text { Assessment of } \\
\text { environmental effects }\end{array}$ & $\begin{array}{l}\text { Unsatisfactory. Significant omissions or inadequacies } \\
\text { observed in the reports. }\end{array}$ & $\begin{array}{l}\text { Has clear requirements for assessment of } \\
\text { environmental effects (EMD article } 5 c \text { ). }\end{array}$ \\
\hline Mitigation & $\begin{array}{l}\text { Satisfactory despite omissions or inadequacies observed } \\
\text { in the ToRs. }\end{array}$ & $\begin{array}{l}\text { Has clear requirements for mitigation } \\
(\text { EMD article } 5 \mathrm{c}) \text {. }\end{array}$ \\
\hline Monitoring & $\begin{array}{l}\text { Unsatisfactory. Significant omissions or inadequacies } \\
\text { observed in the reports. }\end{array}$ & No requirements for monitoring \\
\hline $\begin{array}{l}\text { Consultations and public } \\
\text { participation }\end{array}$ & Satisfactory although parts are not well attempted. & $\begin{array}{l}\text { No provisions for consultation and public } \\
\text { participation }\end{array}$ \\
\hline Report/documentation & Satisfactory. & $\begin{array}{l}\text { Has clear requirements for report content } \\
\text { (EMD chapter } 3) \text {. }\end{array}$ \\
\hline $\begin{array}{l}\text { Incorporation of SEA res } \\
\text { in PPP decision-making }\end{array}$ & $\begin{array}{l}\text { sMost of SEAs were conducted after strategic action } \\
\text { design. Little influence of SEA. }\end{array}$ & $\begin{array}{l}\text { Requirements for incorporation of SEA } \\
\text { results are not explicit (EMD article 6). }\end{array}$ \\
\hline
\end{tabular}

legislation. On the other hand, consideration of alternatives, assessment of environmental effects and incorporation of SEA results in decision-making are questions that obtained unsatisfactory average grades in SEA reports and/or ToRs. However, the new SEA legislation considered these issues. Of particular interest, to this matter, is the consideration of scenarios and incorporation of SEA results in decision-making. Although the Decree requires their consideration, it does not provide specific information on development, selection and types of options to be considered nor how SEA results has to be consider by the decision-maker.

As shown in Table 5, there is no established procedures for consultations and public participation as well as monitoring in the DRC regulations. This may be attributed to the lack of perception amongst developers of the real benefits that may accrue from adopting a participative and continuing approach to SEA despite the additional costs it may entail. There is a need to overcome these omissions to ensure an effective use of this tool.

Legal arrangements in African countries such as Botswana, Cameroon, Guinea Bissau, Kenya, Swaziland, Tanzania and Zambia explicitly address screening, scoping, assessment of environmental effects and documentation principles. Different from other African countries, the Congolese Decree does not provide spe- 
cific requirements to the consideration of alternatives. Likewise, Cameroon regulation make no mention of this principle [68]. The literature on SEA advocates the need to consider alternatives. However, this principle is poorly respected in several countries, such as Canada [56], China [69] and Namibia [70]. There is a need to address the lack of attention paid to alternatives, both in SEA reports and in regulations. [70] argues that more detailed regulation could allow alternatives to be properly identified and evaluated.

According to [68] SEA legislation in Kenya, Swaziland, Tanzania and Zambia does not take into account the principle of monitoring. In Sweden, [71] report the lack of environmental monitoring in the planning of regional transport infrastructure. The EU Directive 2001/42/EC requires the monitoring of significant environmental effects in order to identify any unanticipated adverse effects and to allow for adequate remedial action. However, the Directive and the resulting guidelines for its implementation provide little information on how monitoring should be carried out [72]. Monitoring is intended to address any negative impacts of the strategic action [43]. It is important to strengthen the monitoring of SEA, as this principle strengthens the SEA process and serves as a link between higher and lower decision-making levels [71].

The incorporation of SEA results in PPP decision-making as well as the consultation and public participation were identified as weaknesses in several African countries [68]. However, it is recognized that these requirements are very difficult to implement, especially in low- and middle-income countries [73]. In practice, public awareness of SEA is low [74] and SEA is based on a complex and challenging process [75]. Getting people to understand this process is key to ensuring effective participation by those at the bottom of the ladder [73], and establishing clear requirements contributes to a better integration of SEA results into the decision-making process.

\section{Lessons from DRC}

The findings reported in this paper indicate positive aspects and shortcomings related to the implementation of SEA in the RDC that might be of interest for other countries in which SEA is still to be regulated. The main aspects can be summarised as follows:

1) There is a weak explicit link between the previous practice of SEA and the system being implemented under the new regulation, which must be reinforced in order to learn from the past experience. Despite the benefits in the new legislation, relevant aspects of SEA such as the consideration of alternatives, public consultation and monitoring are still not adequately addressed. [40] have shown some concern regarding the need to assess SEA effectiveness and propose specific changes to the existing procedures. Although there are strong calls to reform or adopt legal arrangements for SEA in developing countries [12] [13] [76], our findings indicate that the adoption of a new legislation wasn't enough to improve SEA practice in the DRC.

2) The initial experience of the RDC seemed to be similar to other countries in 
which the use of SEA is not systematically promoted by the legislation, with a considerable variability in the quality of SEA reports and in SEA effectiveness as well [11] [77]. In the case of the RDC it is suggested that its previous experience with the use of SEA has contributed to stimulate the adoption of mandatory regulations, which is recognized as a positive aspect [17] [27] [76]. Nevertheless, whether a legally-bonded SEA system will contribute to improve the practice is debatable. Legislation can be perceived as being valuable in ensuring the application of the instrument and standardizing the practice [12] [13], but on another hand the lack of a basic set of rules means that each application of SEA might be responsive to its specific context (as demonstrated by [78]).

\section{Conclusions}

The outcomes demonstrated that the overall quality of SEA reports produced in the RDC before the adoption of legal requirements was not satisfactory: only two of the five SEAs reviewed were graded satisfactorily. Regarding ToRs, all of them partially meet requirements. Most of the gaps reported in this paper are related to the development of alternatives and monitoring. In this sense, although the DRC SEA regulations have included the consideration of scenarios, it still lacks from specific requirements about the development of alternatives. Moreover, there is no established procedure for monitoring and public participation. Findings from DRC regulation evaluation against IAIA's performance criteria indicate that the DRC SEA process is considered time-consuming as according to the new regulations the whole DRC SEA process may take 18 months.

Overall, the DRC SEA system is far from fulfilling its potential to enable more effective environmental assessment at PPP levels. Based on our findings, to contribute to an effective use of SEA, the following topics must be considered: 1) the adoption of legal arrangements for SEA does not guarantee improvements in SEA practice; 2) it is necessary to avoid conflicts and include key steps in SEA regulations to ensure an effective use of this instrument.

There is a need to ensure that new regulations demonstrate more precisely how to deliver effective environmental outcomes for PPPs development. Advancing SEA requires focusing not only on the adoption of a SEA processual framework, but also on ensuring a proper use of this tool according to its core principles.

\section{Acknowledgements}

The authors recognize the support of the Brazilian National Council for Scientific and Technological Development-CNPq [research grants \#140402/2015-2 and \#301861/2018-8] and of the São Paulo Research Foundation-FAPESP [research grant \#2017/00095-2].

\section{Conflicts of Interest}

The authors declare no conflicts of interest regarding the publication of this paper. 


\section{References}

[1] Sheate, W.R., Dagg, S., Richardson, J., Aschemann, R., Palerm, J. and Steen. U. (2003) Integrating the Environment into Strategic Decision-Making: Conceptualizing Policy SEA. European Environment, 13, 1-18. https://doi.org/10.1002/eet.305

[2] Fischer, T.B. (2007) The Theory and Practice of Strategic Environmental Assessment: Towards a More Systematic Approach. Routledge, London.

https://doi.org/10.4324/9781849775922

https://www.taylorfrancis.com/books/9781849775922

[3] Tetlow, M.F. and Hanusch, M. (2012) Strategic Environmental Assessment: The State of the Art. Impact Assessment and Project Appraisal, 30, 15-24. https://doi.org/10.1080/14615517.2012.666400

[4] Tshibangu, G.M. and Montaño, M. (2016) Energy Related Strategic Environmental Assessment Applied by Multilateral Development Agencies-An Analysis Based on Good Practice Criteria. Environmental Impact Assessment Review, 61, 27-37. https://doi.org/10.1016/j.eiar.2016.06.007

[5] Rachid, G. and El Fadel, M. (2012) SEA Systems in the Middle East and North Africa Region. WIT Transactions on Ecology and the Environment, 162, 87-96. https://doi.org/10.2495/EID120081 http://library.witpress.com/viewpaper.asp?pcode=EID12-008-1

[6] Walmsley, B. and Patel, S. (2011) Handbook on Environmental Assessment Legislation in the SADC Region. 3rd Edition, Development Bank of Southern Africa (DBSA) in Collaboration with the Southern African Institute for Environmental Assessment (SAIEA), Pretoria.

[7] Alshuwaikhat, H.M. (2005) Strategic Environmental Assessment Can Help Solve Environmental Impact Assessment Failures in Developing Countries. Environmental Impact Assessment Review, 25, 307-317. https://doi.org/10.1016/j.eiar.2004.09.003

[8] Dalal-Clayton, D.B. and Sadler, B. (2005) Strategic Environmental Assessment: A Sourcebook and Reference Guide to International Experience. Earthscan, London, Sterling.

[9] Liou, M. and Yu, Y. (2004) Development and Implementation of Strategic Environmental Assessment in Taiwan. Environmental Impact Assessment Review, 24, 337-350. https://doi.org/10.1016/j.eiar.2003.10.018

[10] Retief, F., Jones, C. and Jay, S. (2008) The Emperor's New Clothes-Reflections on Strategic Environmental Assessment (SEA) Practice in South Africa. Environmental Impact Assessment Review, 28, 504-514. https://doi.org/10.1016/j.eiar.2007.07.004

[11] Malvestio, A.C. and Montaño, M. (2013) Effectiveness of Strategic Environmental Assessment Applied to Renewable Energy in Brazil. Journal of Environmental Assessment Policy and Management, 15, Article ID: 1340007.

https://doi.org/10.1142/S1464333213400073

[12] Wirutskulshai, U., Sajor, E. and Coowanitwong, N. (2011) Importance of Context in Adoption and Progress in Application of Strategic Environmental Assessment: Experience of Thailand. Environmental Impact Assessment Review, 31, 352-359. https://doi.org/10.1016/j.eiar.2011.01.001

[13] Olagunju, A. and Gunn, J.A.E. (2015) First Steps toward Best Practice SEA in a Developing Nation: Lessons from the Central Namib Uranium Rush SEA. Impact Assessment and Project Appraisal, 33, 57-67. https://doi.org/10.1080/14615517.2014.941233

[14] Ashe, J., Marsden, S., et al. (2011) SEA in Australia. In: Sadler, B., Eds., Handbook 
of Strategic Environmental Assessment, Earthscan, London, 21-35.

[15] João, E. and McLauchlan, A. (2014) Would You Do SEA If You Didn't Have to? Reflections on Acceptance or Rejection of the SEA Process. Impact Assessment and Project Appraisal, 32, 87-97. https://doi.org/10.1080/14615517.2014.889265

[16] Morrison-Saunders, A. and Pope, J. (2013) Learning by Doing: Sustainability Assessment in Western Australia, In: Bond, A., Morrison-Saunders, A. and Howitt, R., Eds., Sustainability Assessment. Pluralism, Practice and Progress, Routledge, Oxford, 140-166.

[17] Mota, A.C., La Rovere, E.L. and Fonseca, A. (2014) Industry-Driven and Civil Society-Driven Strategic Environmental Assessments in the Iron Mining and Smelting Complex of Corumbá, Brazil. Journal of Environmental Assessment Policy and Management, 16, Article ID: 1450010. https://doi.org/10.1142/S1464333214500100

[18] Fischer, T.B. and Onyango, V. (2012) Strategic Environmental Assessment-Related Research Projects and Journal Articles: An Overview of the Past 20 Years. Impact Assessment and Project Appraisal, 30, 253-263. https://doi.org/10.1080/14615517.2012.740953

[19] Sandham, L.A. and Pretorius, H.M. (2008) A Review of EIA Report Quality in the North West Province of South Africa. Environmental Impact Assessment Review, 28, 229-240. https://doi.org/10.1016/j.eiar.2007.07.002

[20] Fischer, T.B. (2010) Reviewing the Quality of Strategic Environmental Assessment Reports for English Spatial Plan Core Strategies. Environmental Impact Assessment Review, 30, 62-69. https://doi.org/10.1016/j.eiar.2009.04.002

[21] Sandham, L.A., van Heerden, A.J., Jones, C.E., Retief, F.P. and Morrison-Saunders, A.N. (2013) Does Enhanced Regulation Improve EIA Report Quality? Lessons from South Africa. Environmental Impact Assessment Review, 38, 155-162. https://doi.org/10.1016/j.eiar.2012.08.001

[22] De Montis, A. (2014) Strategic Environmental Assessment of Energy Planning Tools. A Study of Italian Regions and Provinces. Environmental Impact Assessment Review, 46, 32-42. https://doi.org/10.1016/j.eiar.2014.01.006

[23] Noble, B.F. (2009) Promise and Dismay: The State of Strategic Environmental Assessment Systems and Practices in Canada. Environmental Impact Assessment Review, 29, 66-75. https://doi.org/10.1016/j.eiar.2008.05.004

[24] Cashmore, M., Richardson, T. and Axelsson, A. (2014) Seeing Power in International Development Cooperation: Environmental Policy Integration and the World Bank. Transactions of the Institute of British Geographers, 39, 155-168. https://doi.org/10.1111/tran.12011

[25] Grindle, M.S. (2004) Good Enough Governance: Poverty Reduction and Reform in Developing Countries. Governance, 17, 525-548.

https://doi.org/10.1111/j.0952-1895.2004.00256.x

[26] World Bank, University of Gothenburg, Swedish University of Agricultural Sciences and Netherlands Commission for Environmental Assessment (2011) Strategic Environmental Assessment in Policy and Sector Reform: Conceptual Model and Operational Guidance. Environment and Development. World Bank, Washington DC.

[27] Slunge, D. and Loayza, F. (2012) Greening Growth through strategic Environmental Assessment of Sector Reforms: Strategic Environmental Assessment of Sector Reforms. Public Administration and Development, 32, 245-261. https://doi.org/10.1002/pad.1623

[28] Montaño, M., Oppermann, P., Malvestio, A.C. and Souza, M.P. (2014) Current State of the SEA System in Brazil: A Comparative Study. Journal of Environmental As- 
sessment Policy and Management, 16, Article ID: 1450022. https://doi.org/10.1142/S1464333214500227

[29] Liou, M., Yeh, S. and Yu Y. (2006) Reconstruction and Systemization of the Methodologies for Strategic Environmental Assessment in Taiwan. Environmental Impact Assessment Review, 26, 170-184. https://doi.org/10.1016/j.eiar.2005.08.003

[30] Hildén, M., Furman, E. and Kaljonen, M. (2004) Views on Planning and Expectations of SEA: The Case of Transport Planning. Environmental Impact Assessment Review, 24, 519-536. https://doi.org/10.1016/j.eiar.2004.01.003

[31] Hilding-Rydevik, T. and Bjarnadóttir, H. (2007) Context Awareness and Sensitivity in SEA Implementation. Environmental Impact Assessment Review, 27, 666-684. https://doi.org/10.1016/j.eiar.2007.05.009

[32] Van Buuren, A. and Nooteboom, S. (2010) The Success of SEA in the Dutch Planning Practice. Environmental Impact Assessment Review, 30, 127-135. https://doi.org/10.1016/j.eiar.2009.05.007

[33] Yin, R.K. (2009) Case Study Research: Design and Methods. 4th Edition, SAGE Publications, Inc., Thousand Oaks.

[34] Matthews, B. and Ross, L. (2010) Research Methods: A Practical Guide for the Social Sciences. 1st Edition, Pearson, Harlow.

[35] Krippendorff, K. (2003) Content Analysis: An Introduction to Its Methodology. 2nd ed. Sage Publications Inc, Thousand Oaks, California.

[36] Neuendorf, K. (2002) The Content Analysis Guidebook. Sage, Thausand Oaks.

[37] Programme des Nations Unies pour l'Environnement (PNUE) (2012) République Démocratique du Congo Évaluation Environnementale Post-Conflit. Programme des Nations Unies pour l'Environnement, Nairob.

[38] Richardson, T. and Cashmore, M. (2011) Power, Knowledge and Environmental Assessment: The World Bank's Pursuit of "Good Governance". Journal of Political Power, 4, 105-125. https://doi.org/10.1080/2158379X.2011.556344

[39] Cashmore, M. and Axelsson, A. (2013) The Mediation of Environmental Assessment's Influence: What Role for Power? Environmental Impact Assessment Review, 39, 5-12. https://doi.org/10.1016/j.eiar.2012.06.008

[40] Wang, J., Sun, T., Li, P. and Li, F. (2005) Research Progress on Environmental Carrying Capacity. The Journal of Applied Ecology, 16, 768-772. (In Chinese)

[41] Chanchitpricha, C. and Bond, A. (2013) Conceptualising the Effectiveness of Impact Assessment Processes. Environmental Impact Assessment Review, 43, 65-72. https://doi.org/10.1016/j.eiar.2013.05.006

[42] Sadler, B. (1996) Environmental Assessment in a Changing World: Evaluating Practice to Improve Performance. International Study of the Effectiveness of Environmental Assessment. IAIA e Canadian Environmental Assessment Agency.

[43] Therivel, R. (2004) Strategic Environmental Assessment in Action. Earthscan, London, Sterling.

[44] Fischer, T.B. and Gazzola, P. (2006) SEA Effectiveness Criteria-Equally Valid in All Countries? The Case of Italy. Environmental Impact Assessment Review, 26, 396-409. https://doi.org/10.1016/j.eiar.2005.11.006

[45] Lemos, C.C., Fischer, T.B. and Souza, M.P. (2012) Strategic Environmental Assessment in Tourism Planning-Extent of Application and Quality of Documentation. Environmental Impact Assessment Review, 35, 1-10. https://doi.org/10.1016/j.eiar.2011.11.007

[46] Canter, L.W. (2008) Guidance Related to the Summary and Abstract of an EIS. Na- 
tional Oceanic \& Atmospheric Administration, National Marine Fisheries Service, Northeast Regional Office, Gloucester.

[47] Lee, N. and Colley, R. (1987) Reviewing the Quality of Environmental Appraisals. Occasional Paper 24, 2nd Edition, School of Planning and Landscape, University of Manchester, Manchester.

[48] Canadian International Development Agency (2000) How to Perform EvaluationsModel TOR. Canadian International Development Agency.

[49] Independent Evaluation Group (IEG) (2011) Writing Terms of Reference for an Evaluation: A How-To Guide. Communication, Strategy, and Learning International Bank for Reconstruction and Development. World Bank, Washington DC.

[50] New Zealand's International Aid \& Development Agency (NZAID) (2009) NZAID Guideline on Developing Terms of Reference for Reviews and Evaluations. New Zealand's International Aid \& Development Agency, Wellington.

[51] Environment Agency Abu Dhabi (2010) Technical Guidance Document for Terms of Reference (TOR). Environment Agency, Abu Dhabi.

[52] GAO (United States General Accounting Office) (1996) Content Analysis: A Methodology for Structuring and Analyzing Written Material. United States General Accounting Office, Washington DC.

[53] Roberts, C.W. (1997) Text Analysis for the Social Sciences: Methods for Drawing Statistical Inferences from Texts and Transcripts. Lawrence Erlbaum Associates, Mahwah.

[54] United Nations Evaluation Group (UNEG) (2010) Quality Checklist for Evaluation Terms of Reference and Inception Reports. United Nations Evaluation Group.

[55] Fischer, T.B. (2002) Strategic Environmental Assessment Performance CriteriaThe Same Requirements for Every Assessment? Journal of Environmental Assessment Policy and Management, 4, 83-99. https://doi.org/10.1142/S1464333202000905

[56] Noble, B.F. (2003) Auditing Strategic Environmental Assessment Practice in Canada. Journal of Environmental Assessment Policy and Management, 5, 127-147. https://doi.org/10.1142/S1464333203001310

[57] Retief, F. (2007) A Performance Evaluation of Strategic Environmental Assessment (SEA) Processes within the South African Context. Environmental Impact Assessment Review, 27, 84-100. https://doi.org/10.1016/j.eiar.2006.08.002

[58] Sánchez, L.E. and Silva-Sánchez, S.S. (2008) Tiering Strategic Environmental Assessment and Project Environmental Impact Assessment in Highway Planning in São Paulo, Brazil. Environmental Impact Assessment Review, 28, 515-522. https://doi.org/10.1016/j.eiar.2008.02.001

[59] McGimpsey, P. and Morgan, R.K. (2013) The Application of Strategic Environmental Assessment in a Non-Mandatory Context: Regional Transport Planning in New Zealand. Environmental Impact Assessment Review, 43, 56-64. https://doi.org/10.1016/j.eiar.2013.05.007

[60] Bidstrup, M. and Hansen, A.M. (2014) The Paradox of Strategic Environmental Assessment. Environmental Impact Assessment Review, 47, 29-35.

https://doi.org/10.1016/j.eiar.2014.03.005

[61] González, A., Therivel, R., Fry, J. and Foley, W. (2015) Advancing Practice Relating to SEA Alternatives. Environmental Impact Assessment Review, 53, 52-63. https://doi.org/10.1016/j.eiar.2015.04.003

[62] Lamorgese, L., Geneletti, D. and Partidario, M.R. (2015) Reviewing Strategic Envi- 
ronmental Assessment Practice in the Oil and Gas Sector. Journal of Environmental Assessment Policy and Management, 17, Article ID: 1550017. https://doi.org/10.1142/S1464333215500179

[63] Kontić, B. and Dermol, U. (2015) Confronting Reality in Strategic Environmental Assessment in Slovenia-Costs and Benefits. Environmental Impact Assessment Review, 50, 42-52. https://doi.org/10.1016/j.eiar.2014.08.002

[64] Song, Y. and Glasson, J. (2010) A New Paradigm for Environmental Assessment (EA) in Korea. Environmental Impact Assessment Review, 30, 90-99. https://doi.org/10.1016/j.eiar.2009.05.008

[65] Therivel, R. and Minas, P. (2002) Ensuring Effective Sustainability Appraisal. Impact Assessment and Project Appraisal, 20, 81-91. https://doi.org/10.3152/147154602781766717

[66] Runhaar, H. and Driessen, P.P.J. (2007) What Makes Strategic Environmental Assessment Successful Environmental Assessment? The Role of Context in the Contribution of SEA to Decision-Making. Impact Assessment and Project Appraisal, 25, 2-14. https://doi.org/10.3152/146155107X190613

[67] Acharibasam, J.B. and Noble, B.F. (2014) Assessing the Impact of Strategic Environmental Assessment. Impact Assessment and Project Appraisal, 32, 177-187. https://doi.org/10.1080/14615517.2014.927557

[68] Tshibangu, G.M. (2018) An Analysis of Strategic Environmental Assessment Legislation and Regulations in African Countries. Journal of Environmental Assessment Policy and Management, 20, Article ID: 1850002. https://doi.org/10.1142/S1464333218500023

[69] Zhou, K. and Sheate, W.R. (2011) Case Studies: Application of SEA in Provincial Level Expressway Infrastructure Network Planning in China-Current Existing Problems. Environmental Impact Assessment Review, 31, 521-537. https://doi.org/10.1016/j.eiar.2010.10.005

[70] Gils, H.V. (2015) How Often and Why Are Alternatives Absent in Environmental Impact Assessment Practice (EIA) in Namibia? IAIA15 Conference Proceedings. Impact Assessment in the Digital Era. 35th Annual Conference of the International Association for Impact Assessment, Florence, 20-23 April 2015.

[71] Lundberg, K., Balfors, B., Folkeson, L. and Nilsson, M. (2010) SEA Monitoring in Swedish Regional Transport Infrastructure Plans-Improvement Opportunities Identified in Practical Experience. Environmental Impact Assessment Review, 30, 400-406. https://doi.org/10.1016/j.eiar.2009.12.002

[72] Commission of the European Communities (CEC) (2001) Directive 2001/42/EC on the Assessment of the Effects of Certain Plans and Programmes on the Environment.

[73] Walker, H., Spaling, H. and Sinclair, A.J. (2016) Towards a Home-Grown Approach to Strategic Environmental Assessment: Adapting Practice and Participation in Kenya. Impact Assessment and Project Appraisal, 34, 186-198. https://doi.org/10.1080/14615517.2016.1176409

[74] Rega, C. and Baldizzone, G. (2015) Public Participation in Strategic Environmental Assessment: A Practitioners' Perspective. Environmental Impact Assessment Review, 50, 105-115. https://doi.org/10.1016/j.eiar.2014.09.007

[75] Victor, D. and Agamuthu, P. (2014) Policy Trends of Strategic Environmental Assessment in Asia. Environmental Science \& Policy, 41, 63-76. https://doi.org/10.1016/j.envsci.2014.03.005

[76] Silva, A., Netto, M., Selig, P. and Lerípio, A. (2018) Good Practices in Strategic 
Environmental Assessment Processes under the Brazilian Practitioners' Vision. Journal of Environmental Protection, 9, 720-735. https://doi.org/10.4236/jep.2018.96045

[77] Montañez-Cartaxo, L.E. (2014) Strategic Environmental Assessment in the Mexican Electricity Sector. Journal of Environmental Assessment Policy and Management, 16, Article ID: 1450012 . https://doi.org/10.1142/S1464333214500124

[78] Malvestio, A.C. and Montaño, M. (2019) From Medicine to Poison: How Flexible Strategic Environmental Assessment May Be? Lessons from a Non-Regulated SEA System. Impact Assessment and Project Appraisal, 37, 437-451.

https://doi.org/10.1080/14615517.2019.1574390 